Adam Doliwa

Uniwersytet w Biatymstoku

\title{
O ROZUMIENIU I ZNACZENIU SKUSZNOŚCI W PRAWIE PRYWATNYM
}

\section{Prawo prywatne}

Jak wiadomo system prawny to uporządkowany zbiór norm cechujący się formalną zupełnością i spójnością. W układzie pionowym system prawny jest uporządkowany hierarchicznie, zaś w układzie poziomym dzieli się na gałęzie prawa, wyróżniane według różnych kryteriów (np. metody, przedmiotu, podmiotu regulacji). ${ }^{1}$

System prawny można też opisywać za pomocą wyróżnienia pojęć prawa publicznego i prawa prywatnego, które są nazywane „ponadgałęziowymi działami prawa". Za zasadniczy element składowy, w postaci prawa przedmiotowego, decydujący o istocie prawa publicznego, uważa się prawo administracyjne, zaś w odniesieniu do prawa prywatnego rolę taką przypisuje się prawu cywilnemu. ${ }^{3}$ Wyróżnienie $\mathrm{w}$ systemie prawnym składowych $\mathrm{w}$ postaci prawa prywatnego i publicznego ma charakter fundamentalny do tego stopnia, że wpływa na istotę takich gałęzi prawa, jak prawo cywilne i prawo administracyjne. ${ }^{4}$

Rozróżnienie, czy jak chcą niektórzy, podział prawa na prywatne i publiczne ma swoją imponującą, sięgającą starożytności, historię, a współcześnie oparte jest na aprobacie pewnych wartości i określonej ideologii społeczno-politycznej. ${ }^{6}$ Zwo-

Zob. S. Wronkowska, Podstawowe pojęcia prawa i prawoznawstwa, Poznań 2005, s. 104 i n.

Zob. H. Rot, Problem dychotomii prawa publicznego i prywatnego, „Przegląd Prawa i Administracji” 1976, t. VII, s. 23.

3 Zob. Z. Radwański (red.), Zielona księga. Optymalna wizja Kodeksu cywilnego w Rzeczypospolitej Polskiej, Warszawa 2006, s. 13 i n.

4 Zob. Z. Radwański, Pojęcie prawa cywilnego w świetle kodeksu cywilnego (uwagi de lege lata i de lege ferenda), (w:) Polskie prawo prywatne w dobie przemian. Księga jubileuszowa dedykowana Profesorowi Jerzemu MłynarCzykowi, Gdańsk 2005, s. 31.

5 Zob. Z. Duniewska, (w:) System Prawa Administracyjnego (red. R. Hauser, Z. Niewiadomski, A. Wróbel), T. 1, Instytucje prawa administracyjnego, Warszawa 2010, s. 152.

6 Tak J. Nowacki, Prawo publiczne, prawo prywatne, Katowice 1992, s. 132; por. T. Bigo, Związki publicznoprawne w świetle ustawodawstwa polskiego, s. 1 i n. 
lennicy omawianego opisu systemu prawnego w promowaniu pojęć prawa prywatnego i prawa publicznego widzą metodę afirmacji - odpowiednio - autonomii jednostki bądź sprawnej i silnej władzy państwowej (publicznej). ${ }^{7}$

Sformułowane w nauce prawa najważniejsze teorie rozróżnienia prawa na publiczne i prywatne to: teorie interesu; teorie podmiotu i przedmiotu normowania; teorie metody regulacji prawnej; teorie zadań; teorie rzecznika dobra; teorie woli lub inicjatywy stron; teorie władzy publicznej lub podporządkowania; teorie techniki prawodawczej, funkcji prawa i odmienności przepisów prawnych; teorie tradycji; teorie właściwości sądowej; teorie sankcji; oraz liczne teorie mieszane. ${ }^{8}$

Zwykle przedstawiciele nauki prawa znaczenie omawianego rozróżnienia na prawo publiczne i prywatne doceniają, gdyż za jego pomocą dokonać można systematyki - prawa, norm prawnych i metod regulacji prawnej; rozgraniczenia sankcji prawnych i dróg ochrony prawnej; ale także można przeprowadzić systematykę podmiotów stosunków prawnych i ich kompetencji prawnych. ${ }^{9}$

Celowość wyróżniania pojęć prawa publicznego i prywatnego bywa czasem kwestionowana, uznać jednak należy ten zabieg za wartościowy - tak teoretycznie, jak i praktycznie. Przede wszystkim dlatego, że ukazuje różnice co do istoty, w tym funkcji, a także co do metody regulacji wyróżnionych dziedzin i gałęzi prawa, ${ }^{10}$ a przez to także - różnice co do istoty i metody oraz celów działania ich podmiotów (cywilnoprawnych i publicznoprawnych). ${ }^{11}$

Cechą prawa publicznego, w tym zwłaszcza prawa konstytucyjnego i administracyjnego, jest regulacja działalności państwa i innych podmiotów publicznych oraz ludzi jako obywateli w stosunkach z państwem. ${ }^{12} \mathrm{~W}$ prawie publicznym występuje prawne podporządkowanie jednostki podmiotowi (organowi) władzy, a ten ostatni działa w interesie publicznym, interesie ogółu, dążąc do realizacji i ochrony wartości wspólnych dla ogółu.

W prawie prywatnym zaś podmioty stosunków prawnych są równorzędne i względem siebie autonomiczne, a regulacja prywatnoprawna ma przede wszystkim na celu ochronę interesów - w tym majątkowych i osobistych - prywatnych, jednostkowych. ${ }^{13}$

Prawo publiczne w imię interesu publicznego porządkuje stosunki, w które wchodzą jednostki jako obywatele (członkowie państwa) oraz wzajemne stosunki

7
Zob. Z. Duniewska, (w:) System..., op. cit., s. 153.

Omawia przytoczone teorie, odwołując się w tej mierze do niemieckiej doktryny prawniczej, S. Fundowicz, Dychotomiczny podział prawa, ST 2000, nr 1-2, s. 52 i n.; zob. też Z. Duniewska, (w:) System..., op. cit., s. 154 i n.; M. Safjan (red.), System Prawa Prywatnego, T. 1, Prawo cywilne - część ogólna, s. 31 i n.

Zob. S. Włodyka, Problem struktury prawa, PiP 1995, nr 4, s. 7 i n.

Zob. M. Zimmermann, Z zagadnień definicji prawa administracyjnego, AUWr 1964, Prawo, t. XII, s. 16.

Por. J. Nowacki, Prawo publiczne, prawo prywatne, s. 50-69.

Stosunki publicznoprawne między jednostką a państwem polegają także na różnych formach (społecznej i politycznej) „kontroli” sprawowanej przez jednostki nad działalnością państwa (w tym administracji państwowej); jak np. akty głosowania w wyborach, referendach, jak konsultacje społeczne, prawo skargi do sądu administracyjnego.

Por. Z. Duniewska, (w:) System..., op. cit., s. 156 i n. 
państw między sobą. Z kolei prawo prywatne w imię interesu prywatnego porządkuje wzajemne stosunki między jednostkami. ${ }^{14}$

Cechą prawa prywatnego jest to, że treść stosunków prawnych co do zasady kształtują same strony, zwłaszcza za pomocą umowy. Z kolei w prawie publicznym występuje podmiot silniejszy (potentior persona), który narzuca treść stosunku prawnego i dysponuje możliwością użycia przymusu państwowego. ${ }^{15}$ Stosunek prawny kształtowany w oparciu o normy prawa publicznego zakłada zwierzchnią (wertykalną) zależność między stronami, zaś w przypadku stosunku cywilnoprawnego (prywatnoprawnego, horyzantolnego) - takiej zależności brak. ${ }^{16}$ Prawo publiczne, w przeciwieństwie do prawa prywatnego, dotyczy zadań publicznych realizowanych przez podmioty publiczne. ${ }^{17}$

Interesujące $\mathrm{i}$ istotne jest także to, że normy prawa administracyjnego, jako publicznego, stanowią o prawach i obowiązkach władz administracyjnych wobec jednostek (i vice versa), zaś normy prawa cywilnego (prywatnego) - przeciwnie - regulują prawa i obowiązki jednostek w stosunku do innych jednostek. Trafne jest przy tym spostrzeżenie, że korzystając z przepisów prawa prywatnego władza administracyjna zrównuje się z jednostką i ,schodzi do roli podmiotu prywatnego" ${ }^{18}$

We współczesnym piśmiennictwie za główne kryterium wyróżnienia pojęć prawa publicznego i prywatnego, a zarazem za istotną cechę stosunków prawnych i podmiotów podlegających regulacji tak kwalifikowanych norm, obok przedmiotu regulacji i odmienności podmiotów, uznaje się także metodę działania prawa, tj. kształtowania stosunków prawnych i sytuacji prawnych. Jedna metoda - prywatnoprawna, polega na przeważającej równorzędności i autonomiczności podmiotów, druga zaś - publicznoprawna, na dominacji władczości, nadrzędności i podporządkowania. Obie metody są zdeterminowane określonymi założeniami aksjologicznymi w szczególności wyrażanymi w zasadach danej gałęzi prawa.

Nie zachodzi w tej mierze zupełna rozłączność; tak w domenie stosunków regulowanych przez prawo cywilne, jak i administracyjne wskazane wyżej metody nie działają na zasadzie wyłączności. ${ }^{19}$ Co więcej, występuje nawet swoista konwergencja metod regulacji prawnejej ${ }^{20}$ również podmioty prawa publicznego mogą być

14 Zob. J. Nowacki, Prawo publiczne, prawo prywatne, Katowice 1992, s. 9.

15 Zob. J. Radwanowicz, Istota i znaczenie pojęcia przymusu administracyjnego, (w:) J. Zimmermann (red.), Koncepcja systemu prawa administracyjnego, Warszawa 2007, s. 131 i n.

16 Zob. L. Rajca, Gmina jako podmiot władzy publicznej i jako właściciel mienia, s. 76-77.

17 Zob. W. Łączkowski, Ustrojowe podstawy prawa publicznego, (w:) Studia z Prawa Publicznego, T. I, Lublin 1999, s. 15.

18 Tak A. Peretiatkowicz, Podstawowe pojęcia prawa administracyjnego, Poznań 1947, s. 10. Cyt. za Z. Duniewska, (w:) System..., op. cit., s. 157.

19 Zob. E. Łętowska, Umowy - mitologia równości, (w:) S. Wronkowska, M. Zieliński (red.), Szkice z teorii prawa i szczegółowych nauk prawnych, Poznań 1990, s. 50 i n.

20 Zob. na ten temat S. Prutis, Relacje pomiędzy cywilną a administracyjną metodą regulacji prawnej na przykładzie instytucji prawa rolnego, (w:) P. Machnikowski, J. Gołaczyński (red.), Współczesne problemy prawa prywatnego. Księga Pamiątkowa ku czci Profesora Edwarda Gniewka, Warszawa 2010, s. 495 i n. 
stroną stosunków prawnych kształtowanych na zasadzie względnej równorzędności i autonomii. ${ }^{21}$

$\mathrm{Z}$ innej perspektywy odnotowuje się w nauce prawa zjawisko publicyzacji prawa prywatnego, które definiowane jest jako proces odchodzenia od założeń klasycznego prawa cywilnego (np. pacta sunt servanda). ${ }^{22}$

Tego rodzaju uwagi ująć można w formie konkluzji, że „Sfera publiczna nie jest nigdy w pełni publiczna, tak jak sfera prywatna nie jest tylko w pełni prywatna. Prawo publiczne wspólnie z prawem prywatnym kreuje instytucje uregulowane łącznie zazębiającymi się przepisami obu segmentów prawa (...)".23 Albo, inaczej trochę, wyróżniając trzy sfery prawne regulujące działalność administracji, pierwszą traktuje się jako - sferę wyłącznego zastosowania prawa administracyjnego, drugą - wyłącznego zastosowania prawa cywilnego, trzecią zaś - jako sferę graniczną, sferę „krzyżowania się obu reżimów”. ${ }^{24}$

\section{Słuszność w dawnym i we współczesnym prawie prywatnym}

Idea słuszności przenika prawo prywatne. Związek słuszności z prawem, rozumianym jako porządek normatywny, trwa niezależnie od upływu czasu i różnic systemowych (ustrojowych). Idea słuszności przenika współczesne prawo prywatne, którego ,matrycą” jest stanowione prawo cywilne kontynentalnej Europy, ${ }^{25}$ przenika w podobnym stopniu system common law (pod postacią tzw. equity law), ${ }^{26}$ jak również przenikała słuszność dawne rzymskie prawo prywatne (pod postacią tzw. aequitas). ${ }^{27}$ Pisał Stefan Grzybowski, w Dziejach prawa, że ,,Tradycja etycznej i filozoficznej myśli o roli słuszności w porządku prawnym sięga (...) co najmniej do Platona i Arystotelesa". ${ }^{28}$

Aequitas - to rzymskie uosobienie sprawiedliwości. Na rewersach monet rzymskich przedstawiana jako postać kobiety trzymającej wagę i opartej na włóczni; współcześnie wykorzystywaną personifikacją sprawiedliwości jest Temida, bogini grecka. Łacińskie słowo aequitas oznacza m.in. równość, słuszność, jednakowy wymiar sprawiedliwości, prawość. ${ }^{29}$

Witold Wołodkiewicz w Słowniku encyklopedycznym prawa rzymskiego podaje, że aequitas oznaczała ,słuszną sprawiedliwość, kojarząc niezbędny formalizm

\footnotetext{
21 Zob. na ten temat A. Doliwa, S. Prutis (red.), Wypieranie prawa administracyjnego przez prawo cywilne, T. III, Warszawa 2012, passim.

Zob. M. Safjan (w:), M. Safjan (red.), System Prawa Prywatnego, T. 1, Prawo cywilne - część ogólna, Warszawa 2007, s. 47 i n.

23 Z. Duniewska, (w:) System..., op. cit., s. 159.

Tak J.S. Langrod, Instytucje prawa administracyjnego: zarys części ogólnej, Kraków 2003, s. 59. Zob. też Z. Duniewska, (w:) System..., op. cit., s. 167 i n.

Zob. I.C. Kamiński, Słuszność i prawo. Szkic prawno porównawczy, Kraków 2003, s. 27 i n.

Zob. ibidem, s. 80 i n.

Zob. W. Wołodkiewicz, M. Zabłocka, Prawo rzymskie. Instytucje, Warszawa 2001, s. 8 i n.

Zob. S. Grzybowski, Dzieje prawa, Ossolineum 1981, s. 135.

M. Plezi (red.), Słownik łacińsko-polski, T. I, Warszawa 1998, s. 98.
} 
prawa z aplikacją dobra". ${ }^{30}$ Aequitas na grunt prawa przeniesiona została przez retorykę, wpływała na rozwój sztywnego ius civile i na jego interpretację. Jak wiadomo Celsus określał prawo jako sztukę stosowania tego, co dobre i słuszne (ius est ars boni et aequi). Cicero pojmował prawo jako ustanowioną aequitas i przestrzegał, że najwyższe prawo może stać się najwyższym bezprawiem. Paulus podkreślał, że szczególnie w prawie należy mieć na względzie słuszność. Słuszność jest też obecna w zasadach prawa (iuris praecepta) sformułowanych przez Ulpiana. ${ }^{31}$

Słuszność to podstawowa kategoria etyczna, miara etyki jako dziedziny wiedzy. W ujęciu Franza Brentano etyka to jeden z trzech działów filozofii, którego ideałem jest dobro. Słuszność w etyce jest nakazem przedkładania dobra nad zło, pomnażanie dobra jest obowiązkiem moralnym człowieka. ${ }^{32}$

\section{Zasada słuszności}

Ze względu na możliwość i potrzebę systemowego wyodrębnienia prawa cywilnego, nauka prawa rekonstruuje zasady podstawowe tej gałęzi prawa, a wśród nich także zasadę słuszności. Dzięki zasadom podstawowym, ${ }^{33}$ bez względu na różnice w teoretycznym ujęciu ich istoty i zmienny, w zależności od szkoły naukowej, ich katalog, porządek normatywny wyznaczony przez stanowione przepisy prawne wzbogacony zostaje przez reguły prawnonaturalne, takie jak sprawiedliwość, moralność, uczciwość.

Różnica między normą prawa pisanego a normą wynikającą z zasady podstawowej, według Ronalda Dworkina leży w koncepcji stosowania. Reguły prawa, wynikające z prawa pozytywnego, mogą być albo spełnione albo niespełnione, w zależności od faktycznych i prawnych możliwości. Zasady prawa zaś, jako abstrakcyjne standardy moralne, powinny być spełnione zawsze. ${ }^{34}$

Zasada słuszności, jak się to określa w doktrynie, „otwiera” prawo na wartości - wartości, których natura polega na wyborze dobra, na uczciwym postępowaniu w relacjach międzyludzkich. ${ }^{35}$ Aby prawo prywatne było skuteczne i słuszne, powinno być odpowiednio elastyczne, powinno zawierać konstrukcje pozwalające na ochronę zróżnicowanych interesów uczestników obrotu.

\footnotetext{
30 W. Wołodkiewicz (red.), Prawo rzymskie. Słownik encyklopedyczny, Warszawa 1986, s. 21-22.

31 Zob. ibidem.

32 Zob. F. Brentano, Psychologia z empirycznego punktu widzenia, Warszawa 1999, rozdz. VII.

33 Por. Z. Ziembiński, Czym może być teoria prawa cywilnego, (w:) Z zagadnień prawa cywilnego. Profesorowi Andrzejowi Stelmachowskiemu, Białystok 1991, s. 219 i n.

34 R. Dworkin, Biorąc prawa poważnie, Warszawa 1998, s. 60 i n. Zob. też M. Dybowski, Ronalda Dworkina koncepcja zasad prawa, RPEiS 2001, z. 3, s. 99 i n.

35 Zob. A. Bierć, Zarys prawa prywatnego. Część ogólna, Warszawa 2012, s. 49.
} 


\section{Klauzule generalne}

Słuszność, zasada słuszności, choć wyraża powiązanie pomiędzy porządkiem prawnym a wartościami powszechnie akceptowanymi w kulturze europejskiej, to musi być rozumiana jako element uzupełniający, wzbogacający system prawa pozytywnego, a nie czynnik konkurujący, czy wręcz przekreślający pozytywizm prawniczy. Zresztą poszczególne zasady są rekonstruowane przez przedstawicieli doktryny z treści norm prawnych - zawartych w Kodeksie cywilnym, Konstytucji, aktach prawa międzynarodowego.

W szczególności zasadę słuszności można rekonstruować na podstawie norm wyrażających klauzule generalne. Rolą klauzul generalnych i tzw. zwrotów niedookreślonych jest odesłanie do kryteriów i ocen leżących poza systemem prawa oraz dostosowanie regulacji prawa pozytywnego do konkretnego przypadku - przy uwzględnieniu aksjologii systemu prawa prywatnego. ${ }^{36}$

$\mathrm{Na}$ gruncie polskiego prawa prywatnego słusznościowy charakter mają: klauzula zasad współżycia społecznego, której treść, jak pisał A. Stelmachowski, w perspektywie historycznej, jest nowa, ale funkcja, bardzo stara, ${ }^{37}$ klauzula dobrej wiary ${ }^{38}$ oraz klauzula dobrych obyczajów. Przykładem zaś zwrotów niedookreślonych jest należyta staranność (art. $355 \S 1$ k.c.), natura stosunku prawnego (art. $353^{1}$ k.c.). ${ }^{39}$

\section{Słuszność jako istotny czynnik definiujący prawo prywatne. Słuszność w prawie publicznym}

Aby zdefiniować pojęcie prawa cywilnego (prawa prywatnego) odwołać się wystarczy do cywilnoprawnej metody regulacji stosunków społecznych, która jest głównym atrybutem tej gałęzi prawa (przy uzupełniającym znaczeniu elementów przedmiotu i podmiotów regulacji).

M. Safjan stwierdza, że problematyka związana z poszukiwaniem prawa słusznego i sprawiedliwego ma wymiar ogólny i nie ogranicza się wyłącznie do prawa prywatnego. ${ }^{40}$ Chyba jednak da się coś istotnego wyrazić poprzez tezę, że, w perspektywie celu regulacji, czynnikiem definiującym właśnie prawo prywatne (prawo cywilne) jest słuszność. Prawo prywatne rozumiane jako zespół norm ukierunkowanych na ochronę praw podmiotowych uczestników obrotu dąży do realizacji idei prawa słusznego.

Zob. M. Zieliński, Wykładnia prawa. Zasady. Reguły. Wskazówki, Warszawa 2002, s. 163 in.

A. Stelmachowski, Zarys teorii prawa cywilnego, Warszawa 1998, s. 109.

Zob. K. Doliwa, Dobra wiara jako wyrażenie języka prawnego, „Monitor Prawniczy” 2008, nr 6, s. 302 i n.

Zob. A. Doliwa, Prawo cywilne - część ogólna, Warszawa 2012, s. 22-25.

M. Safjan, (w:) M. Safjan (red.), System Prawa Prywatnego, Prawo cywilne - część ogólna, T. 1, Warszawa 2007, s. 296. 
Celem prawa prywatnego, odwołując się do koncepcji G. Radbrucha, jest przywracanie naruszonej równowagi w relacjach między podmiotami prawnymi. ${ }^{41}$ Treść norm prawa prywatnego, służących jako instrument przywrócenia równowagi między uczestnikami obrotu, opiera się na koncepcji słuszności (lex iniustissima non est lex).

Z tym, że w podstawowej mierze treść norm prawa prywatnego opiera się na zasadzie równości, równego traktowania uczestników obrotu oraz na zasadzie pewności, bezpieczeństwa obrotu prawnego. Tym samym urzeczywistnia prawo prywatne ideę sprawiedliwości, czy precyzyjniej mówiąc ideę sprawiedliwości formalnej. Zadaniem prawa jest jednak nie tyle jednoczesne, w równym stopniu, osiągnięcie równości, bezpieczeństwa obrotu i sprawiedliwości - zadaniem prawa jest określony kompromis pomiędzy wskazanymi, głównymi celami. Jak zauważa E. Łętowska, prawo samo w sobie nie jest synonimem moralności i sprawiedliwości; prawo ma umożliwić funkcjonowanie społeczeństwa w sposób możliwie niekonfliktowy. ${ }^{42}$

Tak jak jednak wyżej stwierdzono, prawo prywatne opiera się na słuszności, którą w takim kontekście, celem odróżnienia od pojęcia sprawiedliwości, nazwać można ideą sprawiedliwości moralnej (zasadą prawości prawa). Jest to zasada, która na etapie stosowania prawa umożliwia łagodzenie, korygowanie skutków rygorystycznie pojmowanej idei sprawiedliwości formalnej. ${ }^{43}$

Słuszność jest tym samym kryterium odróżnienia prawa prywatnego od prawa publicznego. Prawo publiczne kieruje się sprawiedliwością dystrybucyjną, celem jego regulacji jest równoważenie interesów prawnych w relacjach ogólnospołecznych.

Nota bene w nauce prawa administracyjnego zasady ogólne są inaczej pojmowane; administratywiści podnoszą postulat opracowania ustawy obejmującej kluczowe, uniwersalne dla prawa administracyjnego, przede wszystkim jego części materialnej, zasady ogólne; zauważają, że odczuwalny jest w prawie publicznym brak części ogólnej, zawierającej podstawowe pojęcia i przewodnie zasady, a także brak kodyfikacji ogarniającej całokształt tego prawa. ${ }^{44}$

Celem prawa prywatnego jest realizacja sprawiedliwości typu wyrównawczego (kompensacyjnego). Słuszność prawa prywatnego polega na równoważeniu interesów w relacjach indywidualnych, ${ }^{45}$ powstających dzięki takim kategoriom, jak prawo podmiotowe, stosunek prawny, umowa. Prawo prywatne, oparte na zasadzie słuszności, umożliwia przywracanie naruszonej równowagi między interesami prawnymi poszczególnych jego podmiotów.

\footnotetext{
41 Zob. T. Chauvin, Sprawiedliwość: między celowością a bezpieczeństwem prawnym. Ewolucja poglądów Gustava Radbrucha, „Studia luridica” 1999, t. XXXVII, s. 15 i n.

42 E. Łętowska, Podstawy prawa cywilnego, Warszawa 1994, s. 21.

43 Zob. A. Bierć, Zarys prawa prywatnego. Część ogólna, s. 48.

44 Zob. Z. Duniewska, (w:) R. Hauser, Z. Niewiadomski, A. Wróbel (red.), System Prawa Administracyjnego, t. 1, Warszawa 2010, s. 112 i tam podaną literaturę. 


\section{Ekskurs}

Zamiast podsumowania pozwolę sobie na koniec uczynić jeszcze pewien dodatek, ekskurs o roli pierwiastka etycznego w poznawaniu i nauczaniu prawa cywilnego. Odwołam się do Fryderyka Zolla (młodszego), który w swym dziele Zobowiąania w zarysie napisał, że ,umiejętności prawa nadaje urok nie tyle znajomość pojęć, zasad i przepisów, co raczej szukanie, odkrywanie i twórcze rozwijanie tego, co logiczne, a zarazem słuszne i dobre”. ${ }^{46} \mathrm{I}$ w innym miejscu „Profesor prawa, cywilista, powinien Studentom nie tylko przedstawić w swych wykładach, czy podręczniku normy prawa obowiązującego i to tak, żeby je oni przyjmowali z wiarą, czy przekonaniem, że wszystko, czego ich uczy, jest prawdziwe i trafne, dobre, celowe i pożyteczne, lecz także - wskazywać im sposób, jak (...) znaczenie (norm prawnych) ustalać i treść ich rozwijać (...) na tle stosunków życiowych, ich podstaw etycznych, celów, wartości ekonomicznych i społecznych, czyli, krótko mówiąc, na tle tzw. natury rzeczy". ${ }^{47}$ 
THE MEANING AND IMPORTANCE OF EQUITY IN PRIVATE LAW

The article presents the essence and importance of private law, as part of the legal system in Poland. It discusses the most important theories which attempt to distinguish between the concepts of private and public law and seeks to define the role of the principle of equity, as an essential distinctive feature of private law. The article also describes the concept of equity in both old and modern civil law and answers the question of how to understand the principle of equity. Specific comments illustrate the operation of the principle of equity on the example of regulations containing general clauses.

Keywords: private law, the principle of equity, general clauses 